\title{
LAVENDER ESSENTIAL OIL FOR SPINAL PAIN IN OBESE WOMEN: A CLINICAL TRIAL
}

\author{
ÓLEO ESSENCIAL DE LAVANDA PARA DOR NA COLUNA VERTEBRAL EM MULHERES \\ OBESAS: UM ENSAIO CLÍNICO
}

\section{ACEITE ESENCIAL DE LAVANDA PARA EL DOLOR ESPINAL EN MUJERES OBESAS: UN ENSAYO CLÍNICO}

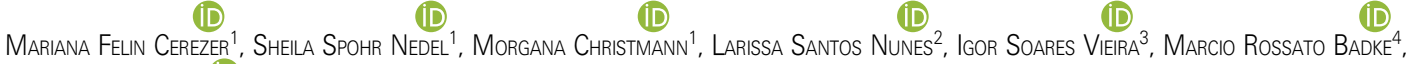 \\ JeRÔNIMO COSTA BRANCO $1,2,3$ \\ 1. Universidade Franciscana. Physical Therapy Course, Santa Maria, RS, Brazil. \\ 2. Universidade Franciscana. Master's in Health and Life Sciences, Santa Maria, RS, Brazil. \\ 3. Universidade Católica de Pelotas. Postgraduate Program in Health and Behavior, Pelotas, RS, Brazil. \\ 4. Universidade Federal de Santa Maria. Santa Maria, RS, Brazil.
}

\begin{abstract}
Objective: To analyze the effect of lavender essential oil associated with massage on spinal pain levels in obese women. Methods: The sample included 49 obese women, between 20 and 60 years of age, randomly assigned to three groups: control ( $n=15)$, intervention $(n=19)$ and placebo $(n=15)$. The intervention and placebo groups were submitted to eight 35-minute sessions, twice a week for one month, but the essential oil of Lavandula angustifolia was used only in the intervention group. A placebo was used for the placebo group and the control group received no intervention. Pain levels were measured before and after the intervention using the Visual Analog Scale. Results: There was a significant decrease in total spinal pain $(p=0.004)$, in the cervical region $(p=0.003)$ and in the lumbar region $(p=0.008)$ in the intervention group. Conclusion: Lavender essential oil had a positive impact on the reduction of pain in the spine of obese women, as well as in the specific areas of the cervical and lumbar regions compared to the control and placebo groups. Level of evidence $\boldsymbol{I}$; Randomized clinical trial.
\end{abstract}

Keywords: Aromatherapy; Back Pain; Lavandula; Obesity.

\section{RESUMO}

Objetivo: Analisar o efeito do óleo essencial de lavanda associado à massagem nos níveis de dor na coluna em mulheres obesas. Métodos: A amostra incluiu 49 mulheres obesas com idades entre 20 e 60 anos, randomizadas em três grupos: controle ( $n=15$ ), intervenção $(n=19)$ e placebo $(n=15)$. Os grupos intervenção e placebo foram submetidos a oito sessões com duração de 35 minutos, duas vezes por semana durante um mês, sendo que o óleo essencial de Lavandula angustifolia foi usado apenas no grupo intervenção. Um placebo foi usado para o grupo placebo e o grupo controle não recebeu intervenção. Os níveis de dor foram medidos antes e depois da intervenção pela Escala Visual Analógica. Resultados: Houve diminuição significativa da dor total na coluna $(p=0,004)$, na região cervical $(p=0,003)$ e na região lombar ( $p=0,008)$ no grupo intervenção. Conclusão: O óleo essencial de lavanda teve impacto positivo na redução da dor na coluna de mulheres obesas, bem como em áreas específicas das regiões cervical e lombar em comparação com os grupos controle e placebo. Nível de evidência l; Ensaio clínico randomizado.

Descritores: Aromaterapia; Dor nas Costas; Lavandula; Obesidade.

\section{RESUMEN}

Objetivo: Analizar el efecto del aceite esencial de lavanda asociado al masaje sobre los niveles de dolor espinal en mujeres obesas. Métodos: La muestra incluyó a 49 mujeres obesas con edades de 20 a 60 años, distribuidas aleatoriamente en tres grupos: control $(n=15)$, intervención $(n=19)$ y placebo $(n=15)$. Los grupos intervención y placebo se sometieron a ocho sesiones con 35 minutos de duración, dos veces por semana durante un mes, utilizándose el aceite esencial de Lavandula angustifolia solo en el grupo intervención. Para el grupo placebo se utilizó un placebo y el grupo control no recibió ninguna intervención. Los niveles de dolor se midieron antes y después de la intervención, utilizando la Escala Visual Analógica. Resultados: Hubo una disminución significativa del dolor total en la columna $(p=0,004)$, en la región cervical $(p=0,003)$ y en la región lumbar $(p=0,008)$ en el grupo intervención. Conclusión: El aceite esencial de lavanda tuvo un impacto positivo en la reducción del dolor de columna vertebral en mujeres obesas, así como en las áreas específicas de las regiones cervical y lumbar en comparación con los grupos control y placebo. Nivel de evidencia I; Ensayo clínico aleatorizado.

Descriptores: Aromaterapia; Dolor de Espalda; Lavandula; Obesidad.

Study conducted at the Universidade Franciscana, Santa Maria, RS, Brazil.

Correspondence: Jerônimo Costa Branco. Rua Silva Jardim, 1175, Santa Maria, RS, Brazil. 97010-491. jeronimobranco@hotmail.com 


\section{INTRODUCTION}

Spinal pains are considered the second most prevalent health condition in Brazil, only behind systemic arterial hypertension, and they can be disabling. ${ }^{1}$ These pains may involve cervical, thoracic, sciatic and lumbar pain, and can result from specific causes such as inflammatory, neoplastic and degenerative diseases and congenital defects in the spine or intervertebral discs. ${ }^{2}$

It is worth mentioning that a woman's life phases are marked by specific anatomo-physiological changes in puberty, pregnancy and climacteric, that favor the appearance of back pain due to the changes in body biomechanics and hormonal changes. ${ }^{3}$ However, these pains are often not the result of a specific disease, but rather of a set of causes, among them, sociodemographic factors, such as age, sex, income, years of school, lifestyle, and metabolic factors, such as excess weight and obesity. ${ }^{4}$

Obesity is considered one of the biggest global public health issues, being a complex chronic multifactorial condition resulting from the excessive accumulation of body fat, mainly in the abdominal region, generated by an imbalance between the intake and expenditure of energy, which causes the individual to develop excess adipose tissues, negatively impacting their health. ${ }^{5}$

Excess weight can increase the risk of numerous conditions associated with pain, among them osteoarthritis, spinal pain and fibromyalgia, and increase the prevalence of chronic pain. This relationship is explained by several factors, including biomechanical tension in the joints and stimulation of a state of systemic inflammation. ${ }^{6}$

There are different ways to relieve and prevent pain, including the regular practice of exercise, pharmacological therapies, surgeries and physical therapy, which has an arsenal of techniques. ${ }^{7}$ In addition, we can mention the Integrative and Complementary Practices (ICPS), such as yoga, acupuncture, homeopathy, phytotherapy and aromatherapy, ${ }^{8}$ which are encouraged by the World Health Organization $(\mathrm{WHO})$ and recognized worldwide.

In Brazil, aromatherapy was regulated by Ordinance No. 702, of March 21, $2018^{9}$ and is popularly used in clinical practice due to its safety, effectiveness, low toxicity and few side effects, ${ }^{10}$ which is why it has been the subject of several studies. ${ }^{10,11}$ Studies using the essential oil of the lavender species, Lavandula angustifolia (LaEO), in different sample populations with reductions in pain levels are found in the literature, such as that conducted in 2106 by Yazdkhasti and Pirak, ${ }^{12}$ in labor, following cesarean sections ${ }^{13}$ and in inflammatory disorders, such as osteoarthritis. ${ }^{14}$

Lavender of the angustifolia species has been used and recognized for its therapeutic effects described in the literature as anticonvulsant, anxiolytic, antioxidant, antifungal, anti-inflammatory and antimicrobial. ${ }^{10,15}$ Thus, the objective of the present study is to analyze the effect of the essential oil of the angustifolia species of lavender associated with massage on spinal pain levels in obese women.

\section{METHODS}

\section{Study design}

This is a randomized clinical trial. The study data were collected in two moments, the first in April and the second in October of 2019.

\section{Participants}

The project was publicized through the Facebook ${ }^{\circledR}$ social network and 60 participants were selected for assessment. The following inclusion criteria were considered: female, body mass index (BMI) from 30 to $45 \mathrm{~kg} / \mathrm{cm}^{2}$, age between 20 and 60 years, presence of spinal pain (cervical, thoracic and lumbar) of any origin with intensity $\geq 3$ on the Visual Analog Scale for pain (VAS) and reporting not having performed any physical exercise in the last three months or having used psychoactive drugs within the last month. The exclusion criteria were: allergy or aversion to LaEO. The data collection and the interventions were conducted at the Physical Therapy Practical Teaching Laboratory (LEP) of the Universidade Franciscana (UFN), Rio Grande do Sul, Brazil.

\section{Assessment}

Questionnaires prepared by the authors were used for the sociodemographic assessment (age, years of school, race, occupation and medication use). To evaluate anthropometry, body weight and height were measured. Body Mass Index (BMI) was calculated using the formula weight divided by height squared, and the participants were classified as underweight (below $18.5 \mathrm{~kg} / \mathrm{cm}^{2}$ ), healthy weight (18.5 to $24.9 \mathrm{~kg} / \mathrm{cm}^{2}$ ), overweight (25.0 to $29.9 \mathrm{~kg} / \mathrm{cm}^{2}$ ) and obese (30.0 kg/cm² and above). ${ }^{16}$

The last three months of physical activity performance were evaluated by the International Physical Activity Questionnaire - IPAQ. ${ }^{17}$

The Visual Analog Scale for pain (VAS) was used to assess the intensity of the pain. The presence of pain in each of the spinal regions (cervical, thoracic and lumbar) was quantified and the three scores were summed and divided by three to measure spinal pain (overall pain). The pain score on the scale for each region ranged from 0 (zero) to 10 (ten), zero indicating absence of pain and ten indicating intense pain. ${ }^{18}$

At the end of the eight sessions, which took place over a period of one month, all the study participants were in the laboratory to perform the same initial tests in order to evaluate the effects of the intervention protocol, comparing them to the placebo and control groups.

\section{Procedures and Randomization}

After the initial assessment of 60 participants and application of the exclusion criteria, we obtained a total sample of 55 obese women able to participate in the study. Subsequently, the patients were randomized into three groups:

Intervention group (G1) - LaEO diluted to $3 \%$ in sweet almond vegetable oil was applied through massage with the aid of heated stones. In addition, 1 (one) drop of the same oil used in the massage was applied to their pillows daily.

Placebo group (G2) - lavender fragrance (without therapeutic properties) diluted in sweet almond vegetable oil was applied by massage with the aid of heated stones, in addition to using 1 (one) drop of the same oil used in the massage to their pillows daily. Control group (G3) - no type of intervention was received, but they were evaluated using the same protocols as the two other groups.

\section{Intervention in G1 and G2}

Each intervention session lasted for 35 minutes, with surface and deep sliding maneuvers applied to all spinal regions with the aid of volcanic stones heated in water to $37^{\circ} \mathrm{C}$. The massage sessions for each group were held in different locations, both air-conditioned environments with a temperature of $22^{\circ} \mathrm{C}$ and sprayed with lavender fragrance to assist in the blinding of the participants. Each participant was massaged by a single physiotherapist (students in the physical therapy course trained by the physical therapist responsible for the study). One (1) drop of the same oil used for the massage was applied to the pillow of each participant before they went to bed on each of the 30 days of the study period.

\section{Blinding}

Groups $\mathrm{G} 1$ and $\mathrm{G} 2$ received the massage under the same environmental conditions, both perfumed with lavender fragrance, in order to blind both participants and therapists. Both were unaware of the group to which they had been assigned. The evaluator of the initial and final interviews had no knowledge of which participant would be in each group nor had any contact with the intervention.

\section{Calculation of sample power}

The estimate for the test of the difference between the mean initial and final scores was calculated. Thus, 49 subjects completed the intervention, 19 of whom were in the intervention group, 15 in the placebo group and 15 in the control group. Thus, the estimated power to test the differences in the mean final scores between the intervention and placebo groups was $70.24 \%$ and between the intervention and control groups was $91.02 \%$. 


\section{Statistical Methods}

The statistical analyses were conducted using SPSS 25.0 software. The descriptive data of the sociodemographic variables were presented as absolute and relative frequencies. The normality of the data was tested using the Shapiro-Wilk test, which identified the asymmetry of the data in relation to the spinal pain, cervical pain, thoracic pain and lumbar pain. To investigate the comparison between pre- and postintervention measurements in the intervention, placebo and control groups, the paired Wilcoxon test was used followed by the Kruskal-Wallis test to examine interclass difference. A significance level of $95 \%$ was adopted for all statistical tests, with a value of $p \leq 0.05$ indicating significance.

\section{Ethical Considerations}

This project received approval from the Universidade Franciscana Institutional Review Board as opinion number 3.254.461 and CAAE 10487919.0.0000.5306. All the patients agreed voluntarily to participate in the study and signed the Informed Consent Form.

\section{RESULTS}

Of the 60 women recruited, there were 30 in the first moment in April and 30 more in the second moment in October of 2019, respecting the physical space of the study location. Of these, 11 did not meet the inclusion criteria, resulting in a sample of 49 participants, randomly assigned to $\mathrm{G} 1(\mathrm{n}=19), \mathrm{G} 2(\mathrm{n}=15)$ and $\mathrm{G} 3$ $(n=15)$ (Figure 1)

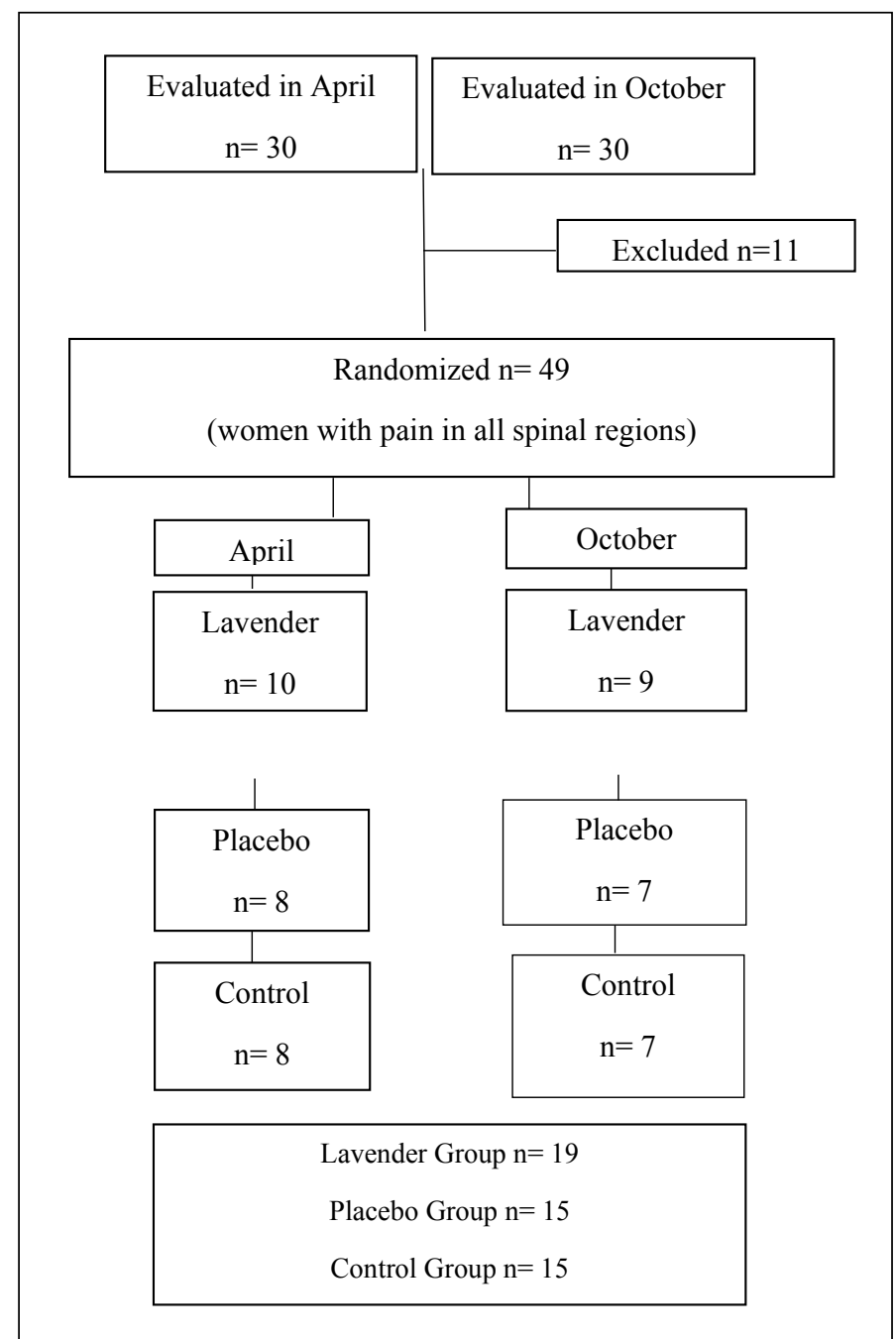

Figure 1. Flowchart of the recruitment and grouping of the participants. Santa Maria, RS, 2019.
Table 1 data presents the sociodemographic characteristics of the sample, with most of the participants between the ages of 40 and 60 years $(65.3 \%)$, White $(75.5 \%)$, married $(77.6 \%)$ and with children $(81.6 \%)$. Causal factors of pain reported included physical effort (30.6\%) followed by injury (22.4\%).

In the comparison of the overall characteristics of the sample, the three groups did not differ in relation to age $(p=0.271)$, years of school $(p=0.610)$, weight $(p=0.169), B M l(p=0.230)$ and the presence of pain $(p \geq 0.05)$, indicating homogeneity among the groups (Table 2 ).

Table 3 shows the pain results for each spinal region before and after the intervention. In the placebo group there was no significant reduction in total spinal pain following intervention $(p=0.064)$ or in any of the specific regions (cervical $p=0.149$, thoracic $p=0.130$, lumbar $p=0.168$ ). Likewise, in the control group, there was no reduction in either total spinal pain $(p=0.203)$ or in any of the specific regions (cervical $p=0.285$, thoracic $p=0.585$, lumbar $p=0.292$ ). In the intervention group we obtained significant reduction values for total spinal pain $(p=0.004)$, cervical region pain $(p=0.003)$ and lumbar region pain $(p=0.008)$.

These results show that using LaEO was responsible for significantly reducing the pain levels of the total spine and the specific cervical and lumbar spinal regions, when compared to the placebo and control groups.

\section{DISCUSSION}

The present study investigated the effect of LaEO associated with massage in relieving spinal pain in obese women. The results showed a significant reduction in pain in the cervical and lumbar regions in the intervention group compared to the placebo and control groups. These findings suggest the use of aromatherapy with $\mathrm{LaEO}$ as an alternative and effective therapy for this population.

The predominant age range in this study was between 40 and 60 years, an age commonly associated with obesity and the presence of chronic pain. Excessive hours working in harmful positions, poor diet and sedentarism are associated with musculoskeletal changes, such as pain, especially in the spine. ${ }^{2,4}$ Among the causal factors of pain reported by the participants were physical effort, the presence of injuries and being obese, which not only result from of excess

Table 1. Sociodemographic characteristics of the study participants.

\begin{tabular}{|c|c|c|}
\hline Variables & $\mathbf{N}$ & $\%$ \\
\hline \multicolumn{3}{|l|}{ Age } \\
\hline $20-40$ & 17 & 34.7 \\
\hline $40-60$ & 32 & 65.3 \\
\hline \multicolumn{3}{|l|}{ Years of school } \\
\hline 0 to 11 years & 27 & 55.1 \\
\hline 12 years and above & 22 & 44.9 \\
\hline \multicolumn{3}{|l|}{ Ethnicity } \\
\hline White & 37 & 75.5 \\
\hline Non-White & 12 & 24.5 \\
\hline \multicolumn{3}{|l|}{ Marital status } \\
\hline Single & 11 & 22.4 \\
\hline Married & 38 & 77.6 \\
\hline \multicolumn{3}{|l|}{ Work } \\
\hline Yes & 21 & 42.9 \\
\hline No & 28 & 57.1 \\
\hline \multicolumn{3}{|l|}{ Children } \\
\hline Yes & 40 & 81.6 \\
\hline No & 9 & 18.3 \\
\hline \multicolumn{3}{|l|}{ Reason for pain } \\
\hline Sedentarism & 6 & 12.2 \\
\hline Injury & 11 & 22.4 \\
\hline Physical effort & 15 & 30.6 \\
\hline Overweight & 9 & 18.4 \\
\hline Emotional & 8 & 16.3 \\
\hline Total & 49 & 100.0 \\
\hline
\end{tabular}


Table 2. Sample characteristics.

\begin{tabular}{|c|c|c|c|c|}
\hline & GC - Control Group & GT - Placebo Group & GI - Intervention Group & p-value \\
\hline & Mean/Median $\left(25^{\circ}-75^{\circ}\right)$ & Mean/Median $\left(25^{\circ}-75^{\circ}\right)$ & Mean/Median $\left(25^{\circ}-75^{\circ}\right)$ & \\
\hline Years of school & $11.6 / 12.0(10.0-15.0)$ & $10.7 / 11.0(8.0-12.0)$ & $10.6 / 11.0(8.0-13.0)$ & 0.610 \\
\hline $\mathrm{BMI}$ & $35.5 / 35.0(31.3-39.7)$ & $38.5 / 38.3(34.7-40.7)$ & $37.5 / 36.4(34.2-41.5)$ & 0.230 \\
\hline Spinal pain & $12.1 / 12.0(8.0-15.0)$ & $9.6 / 10.0(3.0-15.0)$ & $10.7 / 10.0(7.0-18.0)$ & 0.585 \\
\hline Cervical pain & $2.2 / 2.0(0.0-5.0)$ & $1.8 / 1.0(0.0-7.0)$ & $3.8 / 5.0(0.0-7.0)$ & 0.111 \\
\hline
\end{tabular}

Kruskal-Wallis test.

Table 3. Spinal pain results.

\begin{tabular}{|c|c|c|c|c|}
\hline & \begin{tabular}{|c|} 
Pre- \\
Intervention \\
Mean/Median \\
$\left(25^{\circ}-75^{\circ}\right)$ \\
\end{tabular} & \begin{tabular}{|c|} 
Post- \\
Intervention \\
Mean/Median \\
$\left(25^{\circ}-75^{\circ}\right)$ \\
\end{tabular} & $p$-value & Interclass \\
\hline & \multicolumn{3}{|c|}{ Spinal Pain $(n=49)$} & $0.033^{\#}$ \\
\hline Placebo Group $(n=15)$ & $\begin{array}{c}9.6 / 10 \\
(3.0-15.0)\end{array}$ & $\begin{array}{c}6.4 / 5.0 \\
(0-12.0)\end{array}$ & 0.064 & \\
\hline $\begin{array}{c}\text { Intervention Group** } \\
(n=19)\end{array}$ & $\begin{array}{c}10.7 / 10 \\
(7.0-18.0)\end{array}$ & $\begin{array}{l}5.42 / 4.0 \\
(0-10.0)\end{array}$ & 0.004 & \\
\hline Control Group ( $n=15)$ & $\begin{array}{l}12.1 / 12.0 \\
(8.0-15.0)\end{array}$ & $\begin{array}{c}11.0 / 12.0 \\
(6.0-15.0)\end{array}$ & 0.203 & \\
\hline \multicolumn{4}{|c|}{ Cervical Pain $(n=49)$} & 0.221 \\
\hline Placebo Group ( $n=15)$ & $\begin{array}{l}1.86 / 1.0 \\
(0-4.0)\end{array}$ & $\begin{array}{l}0.80 / 0 \\
(0-0)\end{array}$ & 0.149 & \\
\hline $\begin{array}{c}\text { Intervention } \\
\text { Group* }(n=19)\end{array}$ & $\begin{array}{c}3.84 / 5.0(0 \\
-7.0)\end{array}$ & $\begin{array}{l}1.15 / 0 \\
(0-0)\end{array}$ & 0.003 & \\
\hline Control Group $(n=15)$ & $\begin{array}{l}2.2 / 2.0 \\
(0-5.0)\end{array}$ & $\begin{array}{l}1.93 / 0 \\
(0-3.0)\end{array}$ & 0.285 & \\
\hline \multicolumn{4}{|c|}{ Thoracic Pain $(n=49)$} & 0.069 \\
\hline Placebo Group $(n=15)$ & $\begin{array}{l}3.33 / 1.0 \\
(0-8)\end{array}$ & $\begin{array}{l}1.46 / 0 \\
(0-3.0)\end{array}$ & 0.130 & \\
\hline $\begin{array}{l}\text { Intervention Group } \\
(n=19)\end{array}$ & $\begin{array}{l}2.36 / 0 \\
(0-5.0)\end{array}$ & $\begin{array}{l}1.94 / 0 \\
(0-2.0)\end{array}$ & 0.532 & \\
\hline Control Group ( $n=15)$ & $\begin{array}{l}3.8 / 4.0 \\
(0-6.0)\end{array}$ & $\begin{array}{l}3.53 / 4.0 \\
(0-6.0)\end{array}$ & 0.593 & \\
\hline \multicolumn{4}{|c|}{ Lumbar Pain (n=49) } & $0.033^{\#}$ \\
\hline Placebo Group $(n=15)$ & $\begin{array}{l}4.4 / 4.0 \\
(0-8.0)\end{array}$ & $\begin{array}{l}4.13 / 4.0 \\
(0-8.0)\end{array}$ & 0.168 & \\
\hline $\begin{array}{c}\text { Intervention Group** } \\
(n=19)\end{array}$ & $\begin{array}{l}4.57 / 5.0 \\
(1-7.0)\end{array}$ & $\begin{array}{l}2.31 / 0 \\
(0-5.0)\end{array}$ & 0.008 & \\
\hline Control Group $(n=15)$ & $\begin{array}{l}6.13 / 6.0 \\
(5.0-9.0)\end{array}$ & $\begin{array}{l}5.53 / 5.0 \\
(4.0-7.0)\end{array}$ & 0.292 & \\
\hline
\end{tabular}

Note: * ${ }^{*}$ tatistical difference between the initial and final assessments according to the paired Wilcoxon test $(p<0.05)^{\#}$ statistical interclass difference according to the Kruskal-Wallis test, followed by the Student-Newman-Keuls test $(p<0.05)$.

mechanical overload, but also predispose them to inflammatory processes and rheumatic diseases. ${ }^{19}$

Aromatherapy is based on the use of essential oils extracted from the flowers, fruits, seeds, leaves or roots of aromatic plants ${ }^{20}$ through processes such as distillation, infusion, maceration, among other techniques. They can be administered orally, inhaled or absorbed through the skin, providing therapeutic effects according to their prescription. ${ }^{21}$

The results after application of LaEO in a 3\% concentration both in the eight massage sessions and thirty days of inhalation significantly reduced spinal pain in obese women. Other studies have documented this therapeutic action, highlighting the positive effects of essential lavender oil on painful conditions. Yazdkhasti and Pirak ${ }^{12}$ studied women in labor who received LaEO diluted with distilled water to a concentration of $10 \%$ via inhalation at a distance of 5 centimeters from the nose for approximately 3 minutes. The mean pain score results of the experimental group participants were significantly better than the placebo group, which received only distilled water.

In the study by Nasiri et al., ${ }^{14}$ women with osteoarthritis of the knee were divided into three groups. The participants of the intervention group self-massaged with 3\% LaEO for 20 minutes, applied nine times a day for three weeks. The placebo group participants self-massaged the knee with sweet almond vegetable oil at the same frequency for the same period of time. The control group did not perform any massages. The authors of that study reported the beneficial effects of massage with LaEO in terms of pain and functional status, as compared to the placebo and control groups.

The methodology of the present study is similar to those found in the literature and the fact that two means of administration, topical and inhaled, were used may have favored the results observed in the reduction of spinal pain. We attribute the results to the Chemical constituents of LaEO, linalool and linalyl acetate, ${ }^{9}$ which act directly on the central nervous system (CNS), being able to reduce pain and inflammatory processes, in addition to acting as both an anxiolytic and sedative. ${ }^{22}$ Camargo and Vasconcelos ${ }^{23}$ report that a high release of linalool is responsible for the release of nitrous oxide, which is responsible for the algic activity mechanism.

The therapeutic effects of aromatherapy occur through the olfactory system, where, after the aroma of the essential oil is inhaled, it is captured by the olfactory cell receptors and the properties of the essential oil are projected to the olfactory bulbs. Then, the stimulus reaches the olfactory cortex, the temporal lobe structures and the limbic system, ${ }^{20}$ causing specific chemical reactions that generate impulses to the cortical and subcortical areas of the central nervous system, thus being able to act on pain, anxiety, sleep, among others. ${ }^{11}$

Also using eight intervention sessions as a reference, the study by Yip ${ }^{24}$ investigated the combined effects of the stimulation of acupuncture points by electrodes and acupressure with lavender oil to relieve subacute and chronic lumbar pain. The findings show that the participants who received acupuncture point stimulation with lavender oil had a significant reduction in the subjective intensity of pain and an improvement in the objective measurements of functional performance, when compared to using acupuncture point stimulation alone.

Although the results observed in this study are significant, the small sample is a limitation, but adequate randomization of the sample presented homogeneous characteristics across the groups and the scarcity of studies involving LaEO and obese individuals highlights the unprecedented nature of this study. Our results reinforce the importance of the ICPS and the efficacy of essential lavender oil in reducing spinal pain. For further study, we suggest the application of interventions in large samples that include both sexes.

\section{CONCLUSION}

From our results, we concluded that LaEO diluted to $3 \%$ in sweet almond oil significantly reduced total spinal pain, as well as pain in the cervical and lumbar spinal regions, in obese women submitted to an intervention consisting of eight sessions of massage and inhalation of a drop of oil while sleeping for 30 nights, when compared to the placebo group, which received eight sessions of massage and inhaled lavender fragrance, and the control group, which received no intervention.

All authors declare no potential conflict of interest related to this article. 
CONTRIBUTION OF THE AUTHORS: MFC: writing of the work; critical review of its intellectual content; SSN: critical review of intellectual content; interpretation of data for work; MC: substantial contribution to the conception or design of the work; LSN: data interpretation for the job; critical review of intellectual content; ISV: substantial contribution to the design of the work; interpretation of data for work; MRB: substantial contribution to the conception and design of the work; critical review of intellectual content; JCB: substantial contribution to the conception and design of the work; analysis and interpretation of data for work; final approval of the version of the manuscript to be published.

\section{REFERENCES}

1. Instituto Brasileiro de Geografia e Estatística. Pesquisa Nacional por Amostra de Domicílios. Um panorama da saúde no Brasil: acesso e utilização dos serviços, condições de saúde e fatores de risco e proteção à saúde, 2008. Rio de Janeiro: Instituto Brasileiro de Geografia e Estatística; 2010

2. Malta DC, De Oliveira MM, Andrade SSCA, Caiaffa WT, De Souza MFM, Bernal RTI. Factors associated with chronic back pain in adults in Brazil. Rev Saúde Pública. 2017:51(suppl 1):1s-9s. doi: 10.1590/s1518-8787.2017051000052.

3. Oliveira CVA, De Souza DE, Magalhães AG, Silva JPC, Correia GN. Prevalência e fatores associados a problema crônico de coluna em mulheres em idade fértil. Ciênc Saúde Colet. 2020;25(3):1041-9. doi: 10.1590/1413-81232020253.15522018.

4. Ferreira GD, Silva MC, Rombaldi AJ, Wregre ED, Siqueira FV, Hallal PC. Prevalência de dor nas costas e fatores associados em adultos do Sul do Brasil: estudo de base populacional. Rev Bras Fisioter. 2011;15(1):31-6. doi: 10.1590/S1413-35552011005000001.

5. De Oliveira CBC, Brito LA, Freitas MA, De Souza MPA, Rêgo JMC, Machado RJA. Obesidade: inflamação e compostos bioativos. J Health Biol Sci. 2020;8(1):1-5. doi: 10.12662/2317-3076jhbs.v8i1.2785.p1-5.2020.

6. Stokes A, Berry KM, Collins JM, Hsiao CW, Waggner JR, Johnston SS, et al. The contribution of obesity to prescription opioid use in the United States. Pain. 2019;160(10):2255-62. doi: 10.1097/j.pain.0000000000001612.

7. Gosling AP. Mecanismos de ação e efeitos da fisioterapia no tratamento da dor. Rev Dor. 2012;13(1):65-70. doi: 10.1590/S1806-00132012000100012.

8. Mishra S, Singh P, Bunch S, Zhang R. The therapeutic value of yoga in neurological disorders. Ann Indian Acad. Neurol. 2012:15(4):247-54. doi: 10.4103/0972-2327.104328.

9. Montibeler J, Domingos TS, Braga EM, Gnatta JR, Kurebayashil LFS, Kurebayashi AK. Efetividade da massagem com aromaterapia no estresse da equipe de enfermagem do centro cirúrgico: estudo-piloto. Rev Esc Enferm USP. 2018;52:03348. doi: 10.1590/ s1980-220x2017038303348.

10. Cardia GFE. Efeito do óleo essencial de lavanda (Lavandula angustifolia) na resposta inflamatória aguda [dissertação]. Maringá: Universidade Estadual de Maringá; 2018.

11. Domingos TS, Braga EM. Massagem com aromaterapia: efetividade sobre a ansiedade de usuários com transtornos de personalidade em internação psiquiátrica. Rev Esc Enferm USP. 2015;49(3):450-6. doi: 10.1590/S0080-623420150000300013.

12. Yazdkhasti $M$, Pirak $A$. The effect of aromatherapy with lavender essence on severity of labor pain and duration of labor in primiparous women. Complement Ther Clin Pract. 2016;25:81-6. doi: 10.1016/j.ctcp.2016.08.008.

13. Olapour A, Behaeen K, Akhondzadeh R, Soltani F, Razavi FS, Bekhradi R. The effect of inhalation of aromatherapy blend containing lavender essential oil on cesarean postoperative pain. Anesth Pain Med. 2013;3(1):203-7. doi: 10.5812/aapm.9570.
14. Nasiri A, Mahmodi MA, Nobakht Z. Effect of aromatherapy massage with lavender essential oil on pain in patients with osteoarthritis of the knee: a randomized controlled clinical trial. Complement Ther Clin Pract. 2016;25:75-80. doi: 10.1016/j. ctcp.2016.08.002

15. Djenane D, Aider M, Yanguela J, Idir L, Gomez D, Roncales P. Antioxidant and antibacterial effects of Lavandula and Mentha essential oils in minced beef inoculated with $E$. coli 0157: H7 and S. aureus during storage at abuse refrigeration temperature. Meat Sci. 2012:92(4):667-74. doi: 10.1016/j.meatsci.2012.06.019.

16. World Health Organization. Physical status: the use and interpretation of anthropometry Geneva: WHO, 1995

17. Matsudo S, Araújo T, Matsudo V, Andrade D, Andrade E, Oliveira C, et al. Questionário In ternacional de Atividade Física (IPAQ): estudo de validade e reprodutibilidade no Brasil. Rev Bras Ativ Fís Saúde. 2001;6(2):5-12. doi: 10.12820/rbafs.v.6n2p5-18.

18. Hawker GA Mian S, Kendzerska T. French M. Measures of adult pain: Visual Analog Scale for Pain (VAS Pain), Numeric Rating Scale for Pain (NRS Pain), McGill Pain Questionnaire (MPQ), Short-Form McGill Pain Questionnaire (SF-MPQ), Chronic Pain Grade Scale (CPGS), Short Form-36 Bodily Pain Scale (SF-36 BPS), and Measure of Intermittent and Constant Osteoarthritis Pain (ICOAP). Arthritis Care Res (Hoboken). 2011;63(11):240-52. doi: 10.1002/ acr.20543.

19. Marques AB. Associação entre excesso de peso, obesidade, dor músculoesquelética e osteoartrose em cuidados de saúde primários: estudo transversal. Rev Port Med Geral Fam. 2017;33(3):222-8. doi: 10.32385/rpmgf.v33i3.12164.

20. Oliveira CJR, Amaral F. Estresse| ansiedade| aromaterapia: Pelo olhar da Osmologia, ciência do olfato e do odor. Braz J Nat Sci. 2019;2(2):92. doi: 10.31415/bjns. v2i 2.57 .

21. López V, Nielsen B, Solas M, Ramírez MJ, Jager AK. Exploring pharmacological mechanisms of lavender (Lavandula angustifolia) essential oil on central nervous system targets. Frontiers in pharmacology. 2017;8:280. doi: 10.3389/fphar.2017.00280.

22. Machado MP, Ciotta DC, Zanette F, Côcco LC, Biasi LA. Propagação in vitro e caracterização química do óleo essencial de Lavandula angustifolia cultivada no Sul do Brasil. Cienc Rural. 2013:43(2):283-289. doi: 10.1590/S0103-84782013000200015.

23. Camargo SB, Vasconcelos DFSA. Atividades biológicas de Linalol: conceitos atuais e possibilidades futuras deste monoterpeno. Rev Ciênc Méd Biol. 2015;13(3):381-7. doi: $10.9771 / \mathrm{cmbio} . v 13 i 3.12949$.

24. Yip YB, Tse SHM. The effectiveness of relaxation acupoint stimulation and acupressure with aromatic lavender essential oil for non-specific low back pain in Hong Kong: a randomised controlled trial. Complement Ther Med. 2004;12(1):28-37. doi: 10.1016/j. ctim.2003.12.003 